\title{
Too much caution on global warming
}

The much awaited Evans report in the United States is a disappointment, chiefly because it says too little about the prospect of global warming caused by the greenhouse effect. And because it says too little generally.

Sum volumes are none the worse for not being encyclopaedic, and may well be more widely read. Yet there is a sense in which the much-awaited report on greenhouse warming published last week by the National Research Council in Washington could judiciously have been weightier. The Evans report, as the document has been called (after its chairman, previously a US Senator from the State of Washington), to which people have been looking for a resolution of the US government's doubts on global warming, is brief to the point of being laconic, even delphic. And it is late: a few months ago, people were hoping it would see the light of day before last February's climate conference in Washington. Has the extra time been spent winkling out the occasional sentences that might have given offence to to one side or another in what has become a polarized debate?

In the event, the report comes to all the right conclusions, but undemonstratively and with such an air of studied judiciousness that even the middle-of-the-road position that it adopts will not necessarily seem compelling to its readers. Indeed, the most striking and potentially controversial of its recommendations is that there is such a close link between the growth of the world's population and the future potential for global warming occasioned by the greenhouse effect that the "United States should resume full participation in international programs to slow population growth" and should contribute financially towards their cost. It is now roughly a decade since, early in the Reagan presidency, the US government declined to support most international birth-control programmes on the grounds that many of them held abortion to be a birth control method of the last resort. The case for participation is of course compelling, but has Evans reason to believe that the circumstances have changed?

On the more immediate international question, that of the clamour now under way for an international treaty to limit the emission of greenhouse gases, the relevant Evans recommendation is simply that the United States should "participate fully with officials at an appropriate level" in the discussions now under way, "including diplomatic conventions and research and development efforts". But the body of the report, referring to the plan to sign a treaty by June next year, adds the more prescriptive sentence that "the panel believes the United States should fully participate in this process". Hardly fighting talk.

For the United States in particular, the decision that lies ahead about the global warming treaty is at once more complicated and more interesting. There are arguments on either side. There is, for example, something in the general suspicion that some would-be participants in a global warming treaty regard it all as a way of diverting yet more of the prosperity of the United States in their direction. On the other side of that coin, there are practical and almost incalculable considerations of the costs that may arise domestically - the huge amounts of capital that will be needed to maintain supplies of irrigation water at the level US farmers have come to expect. It will be strange if the nation boasting the most substantial research programme in the field stands aside from an international agreement from the fear of what happens to US governments seeking to control the demand for, say, gasoline by increased taxes.

Less tangible arguments also deserved a place in the Evans report. For example, as things are, the United States would be well-placed to ensure that next year's treaty is one that it could live with. So many of the critics of its recent display of unwillingness would be so quickly disarmed by a decision to join that they would sign whatever piece of paper the United States offered. (There are other reasons why the best agreement at this stage would be an agreement to act when research had shown that the time has come to do so, and in what way.) And as things are, the United States is well-placed to shame other recalcitrants, from Saudi Arabia to the Soviet Union, to put their weight behind a treaty. A cool discussion of these and other issues by a committee as influential as that of Evans might have had the scales falling from many pairs of US eyes. The document is an opportunity missed.

\section{Closing Europe's farms}

The latest impending crisis in European agriculture argues for getting people off the land, and quickly.

Prospects for a settlement of the long-standing dispute on agriculture between Europe and the rest of the world are fading fast, to judge from the commotion in Brussels in the past few weeks. By now, the story is familiar. Four years of negotiations towards an improved agreement on international trade under the General Agreement on Tariffs and Trade (GATT) broke down last December. By February, it seemed as if life might be breathed into the corpse of all that work by a change of policy at the European Communities (EC) headquarters in Brussels. But now it emerges that the members of the EC are unable to agree among themselves on how the 